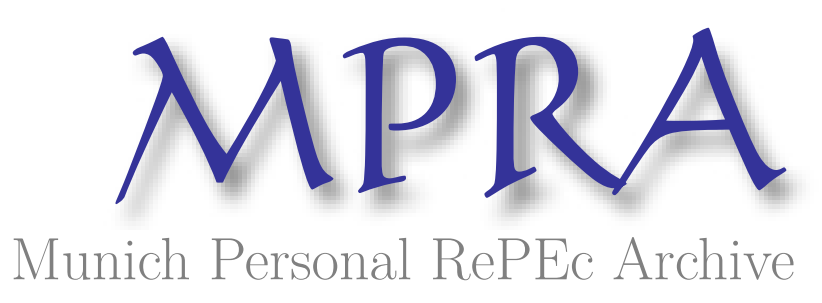

\title{
Traditional comparative advantages vs. economies of scale: NAFTA and GATT
}

Chichilnisky, Graciela

Columbia University

1993

Online at https://mpra.ub.uni-muenchen.de/8359/

MPRA Paper No. 8359, posted 21 Apr 2008 14:26 UTC 
edited by Mario Baldassarri, published by ISER, 1993

\title{
Traditional Comparative Advantages vs. Economies of Scale: NAFTA and GATT $\left.{ }^{*}\right)$
}

\author{
Graciela Chichilnisky \\ Columbia University, New York (NY)
}

\section{1. - Introduction: Trading Blocs and GATT}

Regional free trade zones have been unexpectedly successful in the last decade. Since 1980 the European Community enlarged significantly its membership and its scope. It now includes southern European countries, and market-integrating features allowing goods, people, services and capital to flow freely around an area accounting for about one fourth of world economic output.

In what appears to be a strategic response, the US has been activated to enter into similar agreements with its neighbors. The recent trading and investment agreement with Canada was signed after many decades of doubtful consideration, and the trend is expanding to the rest of the Americas starting with Mexico. The final points needed for the ratification of NAFTA are still undecided (1), even though the US-Canada-Mexico treaty is already signed. This trend is observed also in other regions. The six members of the Association of South East Asian Nations - Singapore, Malaysia,

(*) This article was prepared for the United Nations Program of Trade Liberalization in the Americas, ECLAC, Washington (DC).

(1) The US is currently in the process of imposing steel tariffs on a number of countries including Canada, which is seeking exemption. paper.

N.B.: the numbers in square brackets refer to the Bibliography at the end of the 
Thailand, Indonesia, the Philippines, and Brunei - have begun this year to build their Asean free trade area Afta as a future counterweight to other international trading blocs, even though at present most of their trade is with Europe, Japan and the US and not with each other. The Japanese have increasingly focused their economic attention in their own region, leading to more investment in and imports from the new East Asian manufacturing exporters. Even the Andean Pact seems to be progressing in Latin America after several decades of aimless discussions, with Mercosur following suit.

While regional free trade agreements prosper, the negotiation towards the liberalization of global trade are unsuccessful and stalling, with the agricultural markets being a key negotiating problem. Little goodwill has been generated from the GATT discussions, dispelling hopes for a reversal of fortunes in the near future. While the nature of the GATT negotiations is political, it is reasonable to seek explanations for the situation from an economic viewpoint.

The contrast between the lackluster performance of GATT and the success of the regional trade pacts raises disparate reactions. One view is that the emergence of regional trade pacts is a step in the right direction. In this view free trade is not defunct, but rather being organized and approached differently. But another, quite natural, reaction is to fear that "customs unions", as regional free trade pacts are usually called, are inherently opposed to global free trade. Do customs unions increase free trade with insiders at the cost of diverting trade with outsiders? Since the classic works of Meade [17] and Viner [22] classifying the issues into trade creation and trade diversion, there has been little conceptual advance on this issue. But the issue is very alive today, and requires our full attention.

It is the purpose of this paper to re-examine the positive and negative aspects of trading blocs as they relate to gains from free trade. The paper is primarily a discussion of conceptual issues, although it is based on facts and on particular cases which are of interest to the trade liberalization in the Americas.

We take a somewhat different approach to a familiar issue. Rather than asking the standard question of whether regional blocs help or hinder global free trade, we ask a more detailed question: what type of customs union is likely to lead to a trade war between the 
- have begun this $\mathrm{fta}$ as a future , even though at id the US and not ly focused their ore investment in $\zeta$ exporters. Even in America after ur following suit. the negotiation ssful and stalling, g problem. Little ssions, dispelling hile the nature of eek explanations

ce of GATT and e reactions. One step in the right ut rather being , quite natural, free trade pacts free trade. Do at the cost of of Meade [17] tion and trade this issue. But tention.

1e positive and rains from free ceptual issues, which are of

familiar issue. regional blocs ailed question: ar between the blocs, and what type of customs union is, instead, likely to lead to expanded global trade. In practical terms: what type of trade policies within the blocs will provide economic incentives for expanding free trade.

We shall compare the impact on the world economy of free trade blocs which are organized around two alternative principles: one is traditional comparative advantages, the other is economies of scale. The aim is to determine how the patterns of trade inside the blocs determine the trade relations among the blocs.

The paper has four parts. Section 2 reviews the existing economics of trading blocs, and uses this to explain the current situation in the EC and NAFTA. Section 3 presents a new conceptual approach to the economics of preferential trade, focusing on the internal organization of the trading blocs and the economic incentives that this generates with respect to the rest of the world. Section 4 is a conclusion which pulls the arguments together for an evaluation of NAFTA and an American free trade zone, and of global free trade. The last Section is an Appendix which provides a formal general equilibrium model of trading blocs with increasing returns to scale and proves the mathematical results which underlie the discussion in the text.

\section{2. - The Economics of Trading Blocs}

\subsection{Free Trade and Market Power}

The last ten years have seen new developments in international trade, focusing on the study of economic dynamics and of market imperfections leading to strategic issues in game theory and industrial organization. But the central tenet of the theory remains the Pareto efficiency of the static and competitive world market. In competitive markets, free trade leads to Pareto efficient allocations. There is no way to make a someone better off without making someone else worse off. This is a general proposition which holds for several countries and several markets interacting with each other simultaneously. Called the first theorem of welfare economics, the result that static competitive markets have Pareto efficient equilibria seems to 
loom the larger, the more special cases of market imperfections are pointed out.

In view of the efficiency of competitive markets, the failure of GATT to bring countries to an agreement about a world of free trade seems, at first sight, irrational. It would appear that countries act as if they could, but prefer not to, achieve a Pareto efficient allocation. Indeed, some believe that the failure of GATT is simply a version of the well-known prisoners' dilemma. The words "prisoners' dilemma" are used to describe a generically inefficient situation, one which, with appropriate coordination, can be altered so as to increase the welfare of each and all players.

Such a view would be incorrect. GATT's problems derive not from irrational behavior, nor from a lack of coordination or "prisoners' dilemma". The reason is that while free trade in competitive markets leads to Pareto optimal solutions, free trade may not lead to Pareto efficient allocations when the countries are large and have market power. For example, large countries may freely choose the quantities they export in order to manipulate to their advantage world market prices, in much the same way that a monopolist freely chooses to supply a quantity that maximizes his profits considering its impact on prices, inducing Pareto inferior allocations. For free trade to be Pareto efficient markets must be competitive, and countries must have no market power. When countries are sufficiently large to have an impact on market prices, then they often have an incentive to impose tariffs on each other.

Furthermore, under classical assumptions, a move from tariffs to free trade will typically make some countries better off but other countries worse off. It is true that if a competitive allocation were reached, it would be Pareto efficient. But in a world with tariffs, as we have today, under traditional assumptions some country will lose if free trade is adopted.

One may ask why large countries have protectionist incentives? The reason is that it is possible for large countries to improve their welfare by improving their terms of trade. This is of course not true in competitive markets where the traders, by definition, have no impact on prices. But the theory of trade proves that under traditional assumptions, a large country does have an economic incentive to 
perfections are

the failure of ld of free trade untries act as if ient allocation. a version of the ' dilemma" are ee which, with ase the welfare

ms derive not oordination or ade in competile may not lead large and have ely choose the ivantage world freely chooses ring its impact ee trade to be ountries must , large to have $\mathrm{n}$ incentive to

from tariffs to off but other location were 1 tariffs, as we ry will lose if

st incentives? improve their se not true in ive no impact er traditional incentive to impose tariffs on others. This is the standard theorem on the existence of optimal tariffs, which is discussed in more detail in Section 3.5 below. A tariff can improve the terms of trade of a large country, even though it may distort its production and consumption. What the theorem says is that, under traditional assumptions, there is always an optimal tariff, one at which the gains from increasing its terms of trade through tariffs exceeds the losses due to distortions. A textbook analysis of a simple case is found for example in Krugman and Obsfelt [15]. This theorem is widely accepted, understood and applied.

Of course, the argument in favor of optimal tariffs is not true for small countries. It is essential that the country should be large enough to have the ability to have an impact on prices. Furthermore the larger the country, the more market power it has, and the more it can gain from imposing tariffs on others. The implication of this is that if a world of small competitive economies merges into a few trading blocs, then under traditional assumptions, after the blocs are formed, there are more incentives for imposing tariffs than before. In other words, regional free trade associations, under traditional conditions, lead to protectionism.

The optimal tariff which we have just discussed is imposed by one country on others unilaterally. The theorem does not consider the possibility of retaliation by other countries. But what if they retaliate? What if other countries also impose tariffs in response?

We now move to a world of strategic considerations, a world with tariff wars. Each county imposes tariffs on each other, and does so strategically so as to maximize its welfare given the actions of others. The outcome of this tariff game was studied in Kennan and Riezman [12], [13]. If each country chooses as its tariff the best response to the others', a market equilibrium with tariffs is reached. We call this an optimal tariff equilibrium to distinguish it from the free trade equilibrium.

In an optimal tariff equilibrium some countries are better off than they would be at a free trade equilibrium, Kennan and Riezman [12], [13] and Riezman [21]. In other words, not all countries would benefit if the world were to move from the optimal tariff equilibrium into a world with free trade. Furthermore, these works show that the larger the country, the more it can improve its welfare at the optimal tariff equilibrium from the level that it could achieve at a free trade equilibrium. 
To a certain extent the current situation in the world economy can be described as an optimal tariff equilibrium. Each country imposes tariffs on others strategically. In this light the difficulties of GATT have a reasonable explanation. The unwillingness of countries to agree to multilateral free trade is neither irrational nor a coordination problem. It is a rational response to economic incentives of countries with market power.

One immediate implication is that, under traditional conditions, regional trade blocs which increase the market power of the market participants will naturally lead to tariff wars. The larger the market power of a trade bloc, the greater is its incentive to impose tariffs on others. Even after retaliatory moves are taken into account the same proposition holds: the larger the market power of the bloc, the greater is its possible gain from a tariff war. Therefore if the formation of regional trade blocs increases the market power of the participants, the creation of regional free trade zones encourages trade wars.

We have remarked that the results on optimal tariffs and on the optimal tariffs equilibria hold under traditional assumptions. Since each of these results predicts that regional free trade zones create incentives against global free trade, it becomes crucial to examine the role of these traditional assumptions closely. For whenever these conditions are satisfied, regional free trade inevitably leads to trade wars. And the larger the free trade zones, the more likely it is that they will lead to trade wars.

We shall examine these conditions in some detail in the next section. This examination will be conceptual, but focused on particular cases of immediate interest. Drawing on the classical results on tariffs of Lerner [16] and of Metzler [19], and on new results on trading blocs with economies of scale Chichilnisky [9] reported also in the Appendix, we shall show that if the blocs are organized internally around the principle of economies of scale, the optimal tariff theorem is defeated. This means that, under increasing returns conditions, it is not true that a country is better off by the unilateral imposition of a positive tariff on its imports. But before we turn to the new results, we shall explore the implications of the optimal tariff theorem on the European Community and on NAFTA.

We shall argue that trade patterns can be based on traditional 
world economy Each country e difficulties of iss of countries 1 nor a coordi$c$ incentives of

nal conditions, of the market ser the market pose tariffs on ount the same oc, the greater formation of e participants, rade wars. ffs and on the aptions. Since zones create o examine the nenever these leads to trade it is that they

1 in the next used on parical results on w results on ported also in zed internally ariff theorem nditions, it is pposition of a w results, we orem on the n traditional comparative advantages or on economies of scale. It is to a large extent a matter of policy choice. The trade policies within a trade bloc determine the extent to which the trade bloc will aid or hinder global free trade. The argument for this result, and its implications for trade policy, will occupy the rest of this paper.

\subsection{EC and NAFTA}

We now turn to the possible motivation for the US in forming a free trade zone with its neighbors.

The argument uses simple strategic considerations based on the results discussed in the previous section. NAFTA - and any further extension to a larger free trade zone in the Americas, can be seen as a strategic response by the US to the creation of the European Community trading bloc. The European Community bloc is a free trade zone with a quarter of world output. In seeking to form a trading bloc with its natural trading partners in the Americas, the US appears to respond to the creation of more market power, with an attempt to create more market power. This is a rational response if the US expects a united Europe to impose tariffs on the rest of the world. The emergence of a region with increased market power generally provides an incentive to other regions to seek similar status.

More explanatory power still can be extracted from the results of Kennan and Riezman [12], [13] and Riezman [21] on who wins trade wars. Following the creation of a customs union, the incentives are to create or join another free trade zone, but not at random. The economic incentive is to join another free trade zone with the largest possible market power. This result allows us to predict that the US should not only seek a free trade deal with Canada, but one with as many countries in the Americas as possible. The aim is to reach market power which exceeds that of a unified Europe.

\subsection{Trade Creation and Diversion}

Once a new free trade zone is created, how do we measure the gains and losses from trade? 
A naive view is that since free trade in competitive markets is Pareto efficient, any move towards free trade is positive. As we saw, this would not be correct. We argued that regional trade blocs, being larger than their components, will have more market power and therefore an incentive to impose tariffs against outsiders under traditional conditions. Therefore one of the first negative effects of the formation of a trading bloc is that it can hurt the countries outside these areas. We shall argue below that these negative effects can be mitigated if the trading patterns within the blocs are organized around economies of scale.

But are the damages of free trade zones limited to protectionism with the rest of the world? The answer to this question is generally no. There is a second potential damage in the formation of regional trade blocs. Even if the trading blocs are not accompanied by protectionism against the rest of the world, they can still lead to trade diversions. This means that a regional free trade bloc may lead to the wrong specialization within the bloc. The classical argument about trade diversion is found in Viner [22], whose work remains a benchmark of analysis of preferential trade agreements. We shall summarize his argument here in order to show that, if trading within the blocs is organized around economies of scale, then Viner's argument can break down. With economies of scale, the negative effect of trade diversion can be mitigated. The empirical evidence discussed below suggests that this is what has happened in the European Market since 1958.

The essential argument can be captured from the textbook Table 1:

TABLE 1

THE EFFECTS OF TRADING BLOCS TRADE DIVERSION

\begin{tabular}{|c|c|c|c|}
\hline \multirow{2}{*}{ Cost of veg. oil } & \multicolumn{3}{|c|}{ Tariffs } \\
\hline & 0 & 8 & 12 \\
\hline Germany $\quad \ldots \ldots \ldots \ldots \ldots \ldots \ldots \ldots \ldots \ldots \ldots$ & 20 & 20 & 20 \\
\hline Portugal before EEC $\ldots \ldots \ldots \ldots \ldots \ldots$ & 16 & 24 & 28 \\
\hline Portugal after EEC $\ldots \ldots \ldots \ldots \ldots \ldots \ldots$ & 16 & 16 & 16 \\
\hline USA $\ldots \ldots \ldots \ldots \ldots \ldots \ldots \ldots \ldots \ldots \ldots \ldots \ldots \ldots \ldots$ & 10 & 18 & 22 \\
\hline
\end{tabular}


itive markets is ive. As we saw, ade blocs, being ket power and ers under tradieffects of the untries outside effects can be ganized around

protectionism is generally no. regional trade protectionism de diversions. to the wrong $t$ about trade benchmark of ummarize his $n$ the blocs is rgument can ffect of trade cussed below Market since

the textbook

TABLE 1
There are three countries, Germany, Portugal and the USA. They trade a commodity, vegetable oil. Initially Germany has a tariff that applies equally to all imported oil. If it imports oil despite the tariff, it will buy initially from the USA, which offers the best price. This appears in the second column, showing a low initial tariff. If the tariff is high enough, however, then Germany will produce its own oil, as in column 3. Now if Germany enters into a free trade agreement with Portugal, what are the welfare implications? If the tariff was initially the higher, the welfare of Germany increases after the regional bloc is created, since it replaces its domestic oil with a less expensive oil and uses its domestic resources in more productive sectors. However, if the tariff was initially as in column 3 , after the free trade agreement Germany shifts from American to Portuguese oil, i.e. from a low cost to a higher cost producer. In this case, the free trade zone lowers welfare.

Viner's point is that there are "trade creating" free trade zones, in which the increase in imports by members from one another replaces domestic production. These are desirable. However, free trade blocs could also be "trade diverting" in the case that imports are diverted from a lower cost source outside the bloc to other sources inside the bloc which are less productive, but with more attractive prices after the tariffs were selectively dropped.

The extra trade among the members of the trading bloc is, generally, an improvement of welfare. The trade which is not additional, but a diversion from efficient outside sources to less efficient inside sources lowers welfare. If northern Europe is induced by the entry of southern Europe to buy oil from Portugal rather than an equivalent from the US, and the US source is more efficient but less competitive after the tariffs are dropped in Europe, there has been a welfare loss. Generally speaking Viner's approach evaluates free trade zones by the extent to which more trade is created, rather than existing trade diverted from one source to another.

Viner's original insight remains central to the analysis of preferential free trade zones. But, in practice, it misses an important aspect. The increase size of the market can sometimes lead to more efficiency and competitiveness. Even in the cases where Viner's analysis predicts welfare losses, namely when the trade bloc diverts trade from outside 
sources to less competitive inside sources, welfare can still increase with economies of scale. This can be explained simply in our numerical example. As Portugal expands its oil production due to its new trade to Germany, it becomes more efficient. This appears in Table 2, column 2. After the tariffs were removed Portugal produces and exports more oil and it becomes more competitive, reaching the US level.

TABLE 2

TRADE IS NOT DIVERTED WITH ECONOMIES OF SCALE

\begin{tabular}{|c|c|c|c|}
\hline \multirow{2}{*}{ Cost of veg. oil } & \multicolumn{3}{|c|}{ Tariffs } \\
\hline & 0 & 8 & 12 \\
\hline Germany $\quad \ldots \ldots \ldots \ldots \ldots \ldots \ldots \ldots \ldots \ldots \ldots$ & 20 & 20 & 20 \\
\hline Portugal before EEC $\ldots \ldots \ldots \ldots \ldots \ldots \ldots$ & 16 & 24 & 28 . \\
\hline Portugal after EEC $\ldots \ldots \ldots \ldots \ldots \ldots \ldots \ldots$ & 16 & 10 & 10 \\
\hline USA $\ldots \ldots \ldots \ldots \ldots \ldots \ldots \ldots \ldots \ldots \ldots \ldots \ldots$ & 10 & 18 & 22 \\
\hline
\end{tabular}

Economies of scale can therefore have a major impact on trade policies. We showed that they can check the negative trade diversion effects of a trading bloc. We shall argue in what follows that they can also limit another major negative effect of a trading bloc: the incentives for large blocs with market power to impose tariffs on others.

What does the empirical evidence show? It is widely believed that economies of scale were an important factor in the success of the Treaty of Rome. Economies of scale were central to the success of the European Common Market which was formed in 1958. While a strong possibility for trade diversion existed a priori in the EC, in reality huge inter-industry trade emerged in manufactures. The increase in market size and the associated rationalization in production led to efficiency gains which took precedence over possible trade diversion. Krugman [14] discusses this issue in some detail, without however offering a conceptual relation between economies of scale and the economics of trading blocs. «Hopes for large benefits from both the US-Canada free trade agreement and Europe 1992 rest 
are can still increase imply in our numeriction due to its new is appears in Table 2, rtugal produces and ive, reaching the US

TABLE 2

\section{ES OF SCALE}

\begin{tabular}{c|c}
\hline \multicolumn{2}{|c}{ Tariffs } \\
\hline 8 & 12 \\
\hline & \\
20 & 20 \\
24 & 28 \\
10 & 10 \\
18 & 22 \\
\hline
\end{tabular}

or impact on trade tive trade diversion llows that they can ig bloc: the incenttariffs on others. videly believed that the success of the the success of the in 1958. While a iori in the EC, in ufactures. The intion in production rer possible trade ne detail, without conomies of scale rge benefits from urope 1992 rest largely on an increase in competition and rationalization. In the North American case, the estimate of Harris and Cox, who attempt to take account of competitive/industrial organization effects, suggest a gain for Canada from free trade that is about 4 times larger than those of standard models. In Europe the widely cited and somewhat controversial figure of 7 percent gain due to 1992 presented in the Cechini Report Commission of the European Communities 1988 rests primarily on estimates by Alisdair Smith and Anthony Venables of gains from increased competition and rationalization".

In practice, therefore, economies of scale can defeat trade diversion losses, and transform these into gains. I shall also argue below that they can also defeat the incentives for tariff wars between blocs, so that the formation of trading blocs can become a parallel, complementary effort towards the liberalization of world trade.

\section{3. - Trading Blocs with Economies of Scale}

\subsection{Trade Inside and Between the Blocs}

Although predictions are inherently dangerous in an area so circumscribed by political action, our conclusion is that regional free trade can have different effects on global markets and it should be to a certain extent the choice of well informed and reasonable economic agents which one will prevail.

Regional trading blocs based on traditional comparative advantages will generally divert trade. They will also typically hinder the prospects of global negotiations. In this case, as the bloc has more market power than its parts, it has the incentive to impose larger tariffs on the rest of the world. Regional blocs then develop incentives for imposing tariffs against each other, and for engaging in trade wars. This type of regional free trade zone works against global free trade.

There is, however, an alternative. If the regional trade zones are oriented to the expansion of trade based not on traditional comparative advantages but rather on increased size and on the productive 
efficiency and competitiveness that comes with economies of scale, matters could be quite different. In this latter case, the regional free trade zones could unleash an appetite for further expansion of trade. We shall argue that in this case the incentive for blocs to impose tariffs against each other is reduced, and in fact can be defeated by the economic incentives in favor of trade expansion which accompanies economies of scale. The incentives are now for further expansion of trade. The creation of trading blocs which are organized around economies of scale is therefore part of a broader trend towards increasingly open world markets.

\subsection{The Americas: Traditional Comparative Advantages or Economies of Scale}

A central issue in our argument is the pattern of trade inside the blocs. This issue is of particular importance in an American free trade zone. This is because of all the regions, the American area is the one whose trade is currently based on traditional comparative advantages and on the diversity between the traders' economic development rather than on economies of scale.

The matter is not only one of economic reality: it is also one of perceived economic reality. Both the European and the East Asian countries perceive gains from trade as a matter of exploiting economies of scale. The newly industrialized countries in Asia, and the Japanese, have a dynamic vision of comparative advantages. Moving up the ladder of comparative advantages in the production and trade of skilled-labor manufactures, of consumer electronics, and of products based on specialized knowledge and on technological skill, are widespread priorities.

By contrast, within the sphere of influence of the US, the vision of trade based on traditional comparative advantages still prevails. It permeates to a great extent the thinking about international trade at the government level, at the international organization level, at the academic, and even at the journalist level.

The European free trade zone is, to a certain extent, a zone of equals. To encourage this equality, the introduction of free mobility of 
tomies of scale, he regional free ansion of trade. o impose tariffs lefeated by the h accompanies er expansion of tanized around trend towards

rade inside the ican free trade area is the one ive advantages development

is also one of he East Asian ploiting econAsia, and the tages. Moving ion and trade and of proical skill, are , the vision of prevails. It onal trade at level, at the t, a zone of e mobility of labor has been one of the first steps in the European market integration of 1992.

The Americas, on the other hand, have the US as a hegemon, a "hub" which concentrates on exporting manufactures and skill-intensive goods to the "spokes" in exchange for their resources. The free mobility of labor between the hub and the spokes is an unspoken issue. It has not even been contemplated in the American negotiations for free trade. It has not been mentioned by any of the governments concerned that labor could move freely between the free trade partners, as it does in the EC region. In some cases, quite to the contrary, the free trade agreement has been mentioned as a way to limit the mobility of labor between the concerned countries, such as Mexico and the US.

To the extent that labor remains a fixed input of production within the countries of the American free trade zone, traditional comparative advantages based on labor will be invoked as a foundation for policy. The concern is that an American free trade zone, if it emerges, may reflect the historical patterns of trade between industrial and developing regions, which is usually called North-South trade.

\subsection{Traditional Comparative Advantages and the Global Environment}

Another reason for concern with respect to traditional comparative advantages arises from the current focus on the environment. Traditional comparative advantages emphasize the South's concentration in the production and export of goods which deplete environmental resources, such as wood pulp and cash crops which overuse rain forests, or minerals whose combustion leads to the emission of greenhouse gases. Recent work in the area of North-South trade with environmental inputs to production (Chichilnisky [7], [8]) shows that ill-defined patterns of property rights on forests, fisheries, and arable land in developing countries may lead to a market-induced over-supply of goods which are intensive in the use of these resources as inputs, and to Pareto inefficient patterns of international trade. What 
appears as comparative advantages may simply be a reflection of a market failure in the developing countries. Social and private comparative advantages differ and social and private gains from trade may also differ in these circumstances. Traditional tax policies, levying duties on the use of such inputs in the South, may not work, and may indeed lead to more extraction of the resource and more exports of the resource-intensive commodity. Indeed, it is shown in Chichilnisky [7], [8] that differences in property rights on inputs of production are sufficient to explain the patterns of trade between nations. The global environment is therefore another reason for being concerned with traditional comparative advantages as a foundation for trade. Since two thirds of the current exports from Latin America are resources, and the main trade of Ecuador, Venezuela and Mexico with the US is petroleum, this problem is very real. It is also very real with respect to the trading in wood products which lead to the deforestation of the remaining tropical forests, Amelung [1], Barbier et Al. [2], Binkley Vincent [3], Hyde - Neumann [11]. Replacing traditional comparative advantages with economies of scale could be a necessary feature of a program of sustainable development.

\subsection{Skilled Labor and External Economies of Scale}

It seems desirable at this point to distinguish an important difference between two types of economies of scale: internal to the firm, or external to it. The former are simply a reflection that each firm may be more efficient in the use of its inputs to production as the level of its output increases. The firm's per unit costs decrease with the level of output. Such economies of scale are typical of industries which require large fixed costs, such as aerospace, airlines, and communications networks. This type of increasing returns, called internal, can lead to monopolistic competition or other forms of limitations to market entry. As such, there is a loss to the consumer in that the free market outcomes are typically not Pareto efficient.

There is a different type: external economies of scale. These also lead to a decrease in per unit costs as the output expands, but they do so at the level of the industry or of the country as a whole. Each firm's 
a reflection of a and private comis from trade may policies, levying t work, and may more exports of n in Chichilnisky of production are tions. The global concerned with for trade. Since a are resources, co with the US is w with respect to orestation of the 1. [2], Binkley nal comparative sary feature of a

an important internal to the ction that each oduction as the decrease with al of industries , airlines, and returns, called ther forms of le consumer in o efficient.

ale. These also ds, but they do

le. Each firm's production function faces increasing cost per unit of output, i.e. decreasing returns to scale, which assures competitive behavior. However, as the industry as a whole expands, externalities are created which lead to increased productivity for all the firms. A good example is provided by the electronics industry. Each computer manufacturer faces a rather competitive market. On the other hand, as the overall level of output of the industry expands, knowledge about new technologies develops and this new knowledge, which is easily and rapidly diffused across the industry, leads to lower costs for all. Just about any industry which depends heavily on knowledge has this characteristic. In reality, the factor which leads to increasing returns is the skill of the labor force which embodies knowledge. Knowledge is typically diffused and can be captured and imitated sooner or later, and there are abundant examples in the software and hardware industry to prove this point (2). Knowledge creates skilled labor, and this in turn leads to increasing returns to scale, which usually, although not always, are external to the firm. Because of this skilled labor can simultaneously lead to economies of scale, and to competitive markets. The successful development experience of Korea, of Taiwan, and more recently of the Asian Tigers, showns that export-led policies based on skilled labor intensive goods, for example in consumer electronics, is generally more successful than those intensive in the use of inexpensive and uneducated labor. This point was developed formally in Chichilnisky [4], [6], and more recently in terms of development policies in Dadzie [10].

In this paper we shall concentrate on external economies of scale, which are closely connected with production systems based on skilled labor.

\subsection{Optimal Tariffs: Traditional Theory}

We mentioned above that a large country will typically impose tariffs so as to improve its terms of trade. In doing so it typically

(2) Microsoft's Windows excellent imitation of the Apple operating systems was tested in the US courts and found without fault. 
introduces distortions in its production and consumption. Here we shall show in a simple example how under traditional assumptions there is a tariff that improves welfare, in the sense that the gains from improved terms of trade exceed the losses from distortions. The analysis is completely standard, see e.g. Krugman and Obsfelt [15], but it is included here in order to highlight the differences which arise in economies with increasing returns to scale. This is discussed in the next section.

The analysis in this section relies on one assumption and one simplification. Both are raised in the Appendix, which consider the general case. The assumption here is that the supply and demand curves of the economy are linear and exhibit decreasing returns to scale, and that there are no major income effects. The simplification is to neglect the impact of the tariff revenues on income; this is typically done in textbooks, and will also be done in this section. It is however explicitly analyzed in the Appendix.

We assume that the home country $H$ has a demand curve with equation:

$$
D=a-b \tilde{p}
$$

where $\tilde{p}$ is the domestic price of the good and a supply curve:

$$
Q=e+f \tilde{p}
$$

Country $H$ 's demand for imports is the difference:

$$
D-Q=(a-e)-(b+f) \tilde{p}
$$

Foreign export supply is also a straight line:

$$
\left(Q^{*}-D^{\star}\right)=g+h p_{w}
$$

where $p_{w}$ is the world price. The internal price in country $H$ exceeds the world price by the tariff:

$$
\tilde{p}=p_{w}+t
$$


imption. Here we ional assumptions hat the gains from distortions. The and Obsfelt [15], ences which arise is discussed in the

umption and one hich consider the ply and demand easing returns to e simplification is $\mathrm{e}$; this is typically on. It is however nand curve with

pply curve:

intry $H$ exceeds

In a world equilibrium imports must equal exports:

$$
(a-e)-(b+f) \times\left(p_{w}+t\right)=q+h p_{w}
$$

Solving equation (6) for $t=0$ gives $p_{f}$, the world price that would prevail without tariffs. Then a tariff $t$ alters the internal price to:

$$
\tilde{p}=p_{f}+t h /(b+f+h)
$$

and the world price to:

$$
p_{w}=p_{f}-t(b+f) /(b+f+h)
$$

Note that if the parameters $a, e, b, h$ and $f$ are all positive, then:

$$
p_{f}<\tilde{p} \text { and } p_{w}>p_{f}
$$

implying that the tariff raises the internal price $\tilde{p}$ and lowers the world price $p_{w}$.

It is immediate to show that, under these conditions, it is always possible to find a tariff $t$ that increases the country's welfare. Let $q_{1}$ and $d_{1}$ be the free trade levels of consumption and production. Since the internal price is higher after the tariff, domestic supply rises from $q_{1}$ to $q_{2}$ and demand falls from $d_{1}$ to $d_{2}$ :

$$
q_{2}=q_{1}+t f h /(b+f+h)
$$

and:

$$
d_{2}=d_{1}-t b h /(b+f+h)
$$

The gain in welfare from a lower world price is the area of the rectangle in Graph 1, the fall in the price multiplied by the level of imports after the tariff:

$$
\begin{gathered}
\text { gain in welfare }=\left(d_{2}-q_{2}\right) \times t(b+f) /(b+f+h)= \\
t \times\left(d_{1}-q_{1}\right) \times(b+f) /(b+f+h)-(t)^{2} \times h(b+f)^{2} /(b+f+h)^{2}
\end{gathered}
$$


GAINS AND LOSSES FROM TARIFFS: TRADITIONAL CASE

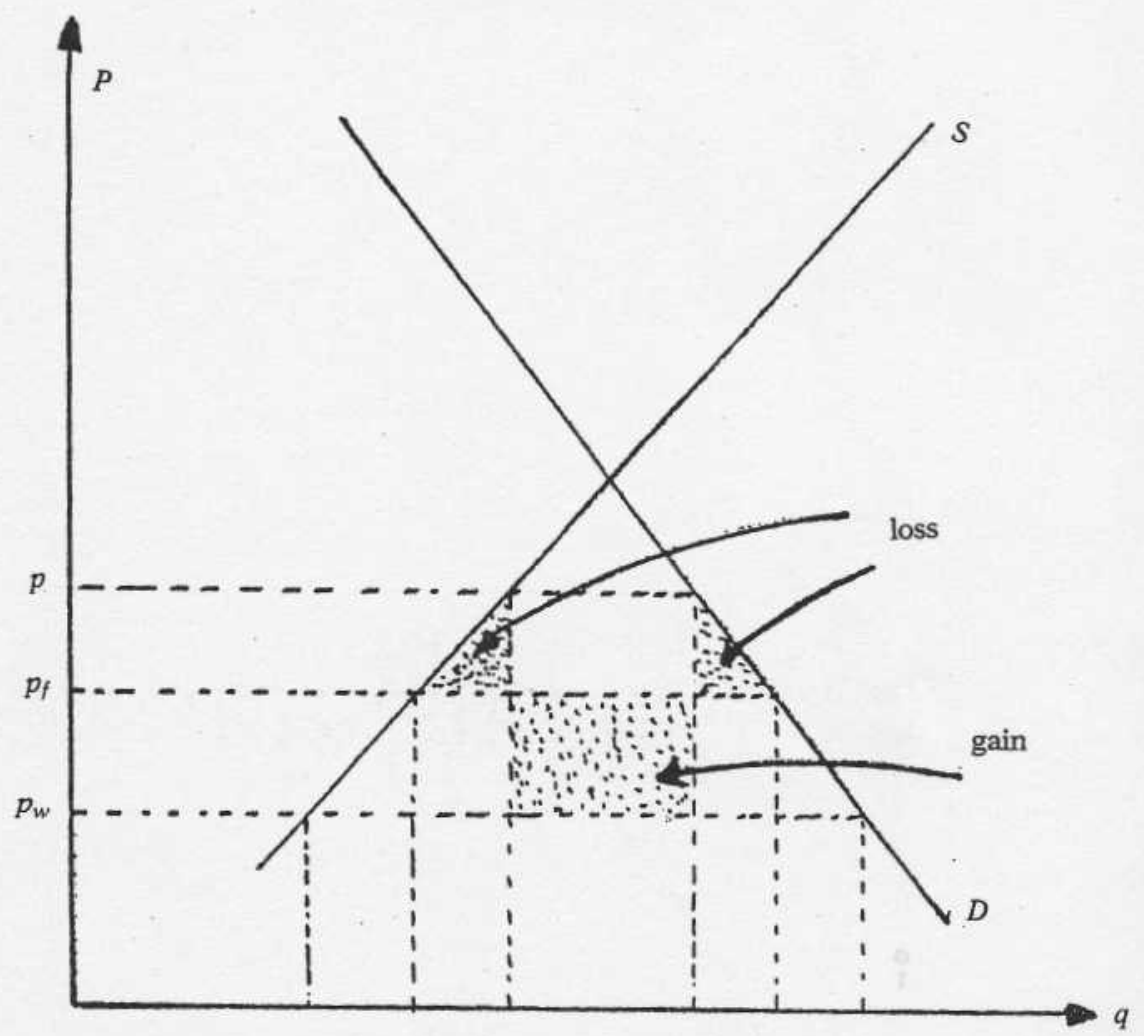

The loss from distorted consumption is the sum of the areas of the two triangles in Graph 3:

(13) loss in welfare $=(1 / 2) \times\left(q_{2}-q_{1}\right) \times\left(\tilde{p}-p_{f}\right)+$ $+(1 / 2) \times\left(d_{1}-d_{2}\right) \times\left(\tilde{p}-p_{f}\right)=(t)^{2} \times(b+f) \times h^{2} / 2(b+f+h)^{2}$

The net effect on welfare is therefore:

$$
\text { gain-loss }=t \times U-(t)^{2} \times V
$$


where $U$ and $V$ are constants. The net effect is the sum of a positive number times the tariff rate and a negative number times the square of the tariff rate. It follows that when the tariff is sufficiently small the net effect must be positive, since $t^{2}$ is smaller than $t$, for $t$ near zero. This establishes that, when supply and demand, income effects of the tariff income are neglected and are linear and tariffs are small, there exists a positive tariff which increases the welfare of the country beyond that which can be obtained under free trade.

The size of the country matters. If the importing country is small, then foreign supply is highly elastic i.e. $h$ is very large, so from (8) we verify that the tariff has little or no effect on world prices $p_{w}$ while raising domestic prices $\tilde{p}$ almost one-to-one.

\subsection{Optimal Tariffs with Economies of Scale}

The argument in the previous section shows that a large country is better off by imposing tariffs than it is under free trade. This proposition holds under traditional conditions, one of which is that the supply of goods should increase with prices across market equilibria. In our example, this is formalized by the parameters in the supply function in equation (2), which is upward sloping. However, this assumption ceases to be valid when the economy has economies of scale. In such economies the larger the output the lower the costs, and therefore, in principle, the lower the prices. Then $f<0$ in equation (8), which in turn can lead to a negative welfare gain from the tariff from equation (12).

A good example of this phenomenon is provided by the electronics industry, for example computer hardware. The last fifteen years have seen a dramatic decrease in prices together with a dramatic expansion of output of computer hardware. This occurs because the expansion in output leads to rationalization and the corresponding increased efficiency in production. In the hardware industry this takes the form of technological change which improves productive efficiency and lowers the costs of the industry as a whole. Even though a technological breakthrough may in principle be patented, and therefore could be captured by one firm with the corresponding increase in 


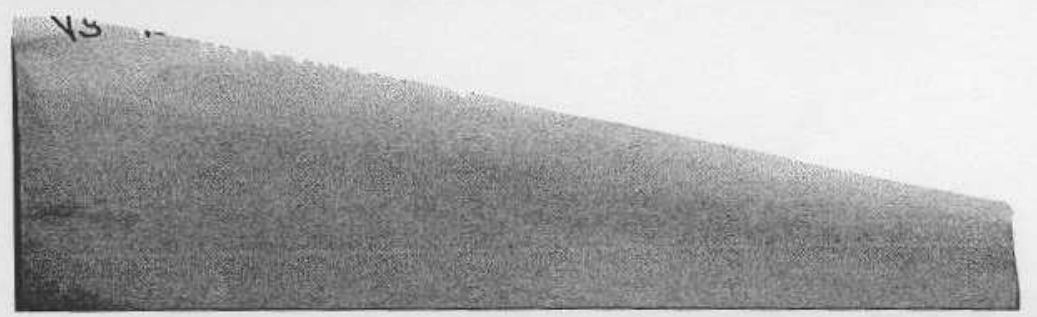

its market power and deviation from competitive behavior, in practice the computer industry is very competitive. This is because the knowledge which drives the technological innovation in this industry is easily diffused.

A standard textbook analysis of such economies of scale is for example Nicholson [20], pages 252-5, who documents that most studies of long-run cost curves have found that average costs are decreasing up to a point and then constant. Examples provided are agriculture, electricity generation, railroads, and commercial banking, all activities which are broadly associated with economic development. The same textbook analysis explains how competitive markets can lead to a negative association of quantities and prices across equilibria. This was the content of the famous debate in the 1920's between J.H. Clapham, A.C. Pigou and D.H. Roberston, which was resolved positively, and which appeared in the Economic Journal between 1922 and 1924 (3). Chichilnisky and Heal [5] have discussed in some detail the policy implications of international trade in economies with increasing returns to scale in a report on trade policies in the 1980's to the Secretary General of UNCTAD, and they reach similar conclusions.

We shall now show how the analysis of optimal tariffs in the last section breaks down when there are increasing returns to scale. In such economies there may be no gains from imposing tariffs, even if the country is large and has substantial market power. The optimal tariff theorem no longer holds. We shall now explain how this happens in a concrete case.

It is useful to remind ourselves how tariffs increase welfare in the economy of the previous section. Tariffs increase welfare by lowering the world prices $p_{w}$ : this was seen in equation (7). The country's terms of trade thus improve after the tariff. It imports fewer lower cost goods from the rest of the world. The welfare gains were computed in equation (12): these depend crucially on the fact that, after the tariff, the consumers pay lower prices for the goods they import.

However, this argument no longer holds with economies of scale. With economies of scale the world price may increase rather than

(3) See Nicholson [20], p. 332. 
1avior, in practice ecause the know1 this industry is

es of scale is for ments that most iverage costs are les provided are imercial banking, onomic developapetitive markets nd prices across ate in the 1920's ston, which was conomic Journal ] have discussed al trade in econtrade policies in and they reach

tariffs in the last irns to scale. In $\mathrm{g}$ tariffs, even if er. The optimal plain how this

e welfare in the are by lowering country's terms wer lower cost re computed in after the tariff, mport.

nomies of scale. se rather than decrease after the tariff. The welfare gains from tariffs are the drop in world prices times the quantity imported. But if the world price increases, the gains are transformed into losses.

The possibility that after a tariff the terms of trade deteriorate for the country was studied in Lerner [16] and Metzler [19]. They argue mostly in terms of income effects. A similar phenomenon occurs in our economy, but due to different causes. In contrast with the economy of the previous section, the parameter $f$ in equation (8) is now negative rather than positive; this means that across equilibria the prices drop as quantities increase, or otherwise said, prices increase when quantities drop. If the tariff decreases the quantity produced and traded, this will lower the productive efficiency of the economy. Costs increase and therefore prices increase too. The tariff defeats the gains from rationalization in production produced by the larger market size. This is represented in Graph 2. It shows a negative correlation between market clearing prices and the quantity of goods sold at an equilibrium, and how this leads to an increase in the world prices after the tariff, corresponding to a decrease in output.

We saw that after the tariff, the world price $p_{w}$ can be higher rather than lower as it is in the traditional case with decreasing returns to scale. The terms of trade for the country are therefore worse after the tariff. Consumers in the country are worse off: the price of their imports have increased. All of this is formally reflected in the systems of equations presented above. In equation (7) the parameter $f$ describing the relation between supply and prices, which was previously positive, is now negative. In practical terms the following conditions are sufficient for the world price to increase rather than decrease after the tariff:

$$
\begin{gathered}
b<|f|<h \\
f<0, b, h>0
\end{gathered}
$$

Conditions (15) are satisfied under a variety of circumstances. For example (15) holds when foreign export supply increases with, and is highly responsive to, prices ( $h>0$ and large), a resonable assumption for the world, when the country has increasing returns to scale $(f<0)$ 
LOSSES FROM TARIFFS WITH ECONOMIES OF SCALE
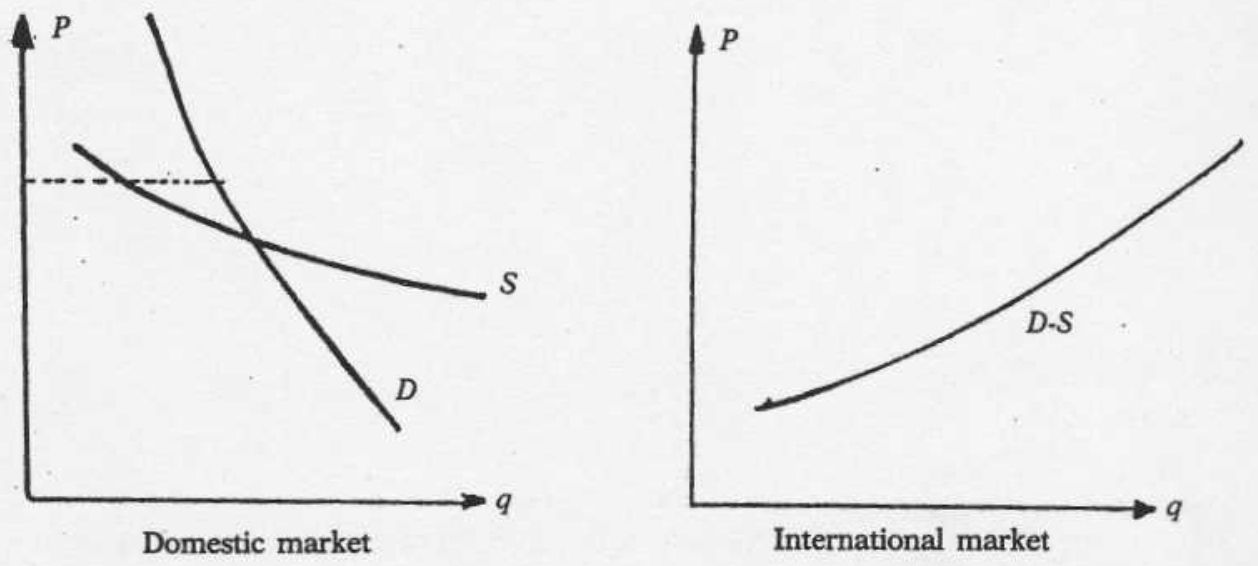

AFTER THE TARIFF, THE WORLD PRICE $p_{w}$ INCREASES DUE TO ECONOMIES OF SCALE

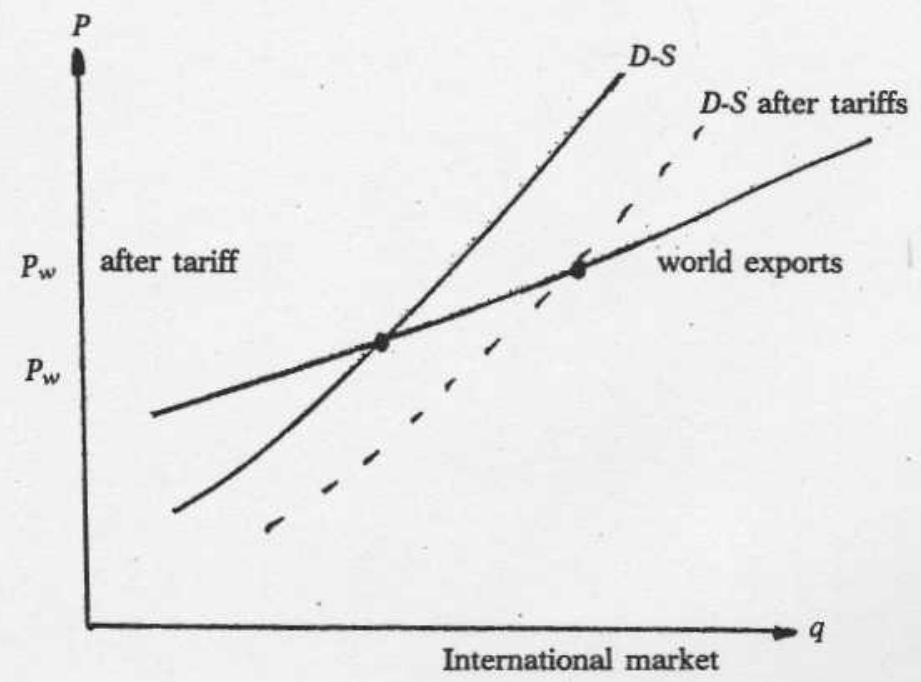


GRAPH 2

\section{OF SCALE}

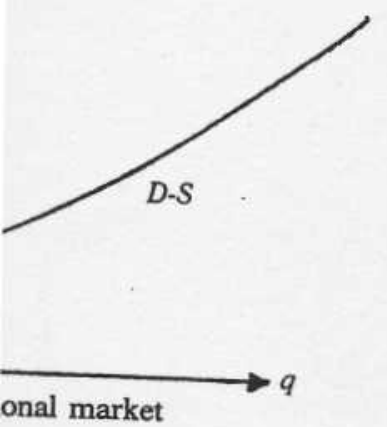

REASES and the quantity produced is more responsive to price than is the demand $(b>0, b<|f|)$.

The main condition is the existence of economies of scale in the economy $(f<0)$. Under these conditions, the optimal tariff theorem is no longer true, as the countries may have no economic incentive to impose tariffs on others: they lose by restricting trade.

Consumer electronics, semiconductors, software production, banking and financial services, and just about any sector whose productivity depends mostly on knowledge and information have these characteristics. Software production is today actively developed in India as an export business. It is a sector which is simultaneously labor intensive and subject to informational economies of scale. As already discussed, the remarkable economic development of the Asian Tigers over the last fifteen years profited from the expansion of their international trade of skilled-labor intensive products such as consumer electronics. This sector is simultaneously labor intensive and subject to informational economies of scale.

All the arguments just presented hold equally for countries or for trading blocs. To the extent that sectors with economies of scale expand within the free trade zone, the zone itself loses its economic incentives to use its market power to restrict trade and wage tariff wars against others.

\section{4. - Conclusions}

We have argued that the formation of trading blocs typically harms the global liberalization of markets when the blocs are themselves organized under the principle of traditional comparative advantages. Under these conditions, the larger the market power of the bloc the greater its incentives to impose tariffs on others. Protectionism emerges from the increased market power of the traders.

Relation can lead to a tariff war between the blocs. Furthermore under traditional assumptions, the larger country wins the tariff ware. Therefore the larger the trading bloc, the more likely it is to impose tariffs and to win a trade war.

Trading blocs of this nature have no economic incentive to favor 
the GATT negotiations. They are better off with tariffs than with free trade. Indeed, the economic incentives of such trading blocs are contrary to the GATT's intentions. We argued that, to a certain extent, this explains the floundering of the GATT negotiations.

We discussed the example of the EC bloc in contrast with NAFTA or with an eventual American free trade zone. The empirical evidence suggests that the EC trading bloc benefited from increasing returns to scale.

NAFTA, and any eventual America free trading bloc, emerged as a strategic response to the increased market power of the European trading bloc. By contrast with the $\mathrm{EC}$ trading bloc, the emerging NAFTA appears to be organizing under the traditional theory of comparative advantage.

The lack of any provision for the mobility of labor between the countries of the region reinforces this trend. NAFTA does not contemplate the mobility of labor between Mexico and the US. The lack of labor mobility tends to lock-in the traditional comparative advantages between the countries within the area. Their trading on the basis of comparative advantages within bloc will create incentives for trade wars between the blocs.

A different scenario contemplates a NAFTA organized around economies of scale. Example for such scenarios include the Indian software trade, and the Asian Tigers' specialization in consumer electronics. Typically, electronic-based industries have increasing returns derived from the creation and diffusion of knowledge as output expands. This leads to rationalization in production and to increased efficiency and thus lower costs. The expansion of output is accompanied by lower rather than higher prices. From the point of view of the exporter, these markets are less likely to be protected because the importer, having increasing returns to scale in this industry, has less incentives to rely on tariffs than it does in other industries with decreasing returns. With increasing returns, tariffs decrease trade and can increase world prices, thus decreasing the welfare of the importing country. Economies of scale produce incentives to expand trade.

We formalized this issue by showing that economies of scale can defeat the standard result of optimal tariffs. While under traditional 
fs than with free ading blocs are a certain extent, ns.

rast with NAFTA apirical evidence easing returns to

loc, emerged as of the European , the emerging onal theory of

or between the es not contemJS. The lack of tive advantages on the basis of tives for trade

anized around ade the Indian in consumer ive increasing knowledge as uction and to on of output is $n$ the point of be protected scale in this does in other eturns, tariffs ecreasing the oduce incents of scale can er traditional conditions, a trading bloc is always better off with tariffs than it is with free trade, we showed that with increasing returns to scale this is no longer true. Tariffs decrease the size of the market, and therefore decrease productive efficiency in economies with increasing returns. This decrease in efficiency leads lo increased rather than lower world prices, and the main purpose of the tariff, which is to improve the countries' terms of trade, is defeated. Under these conditions trading blocs are better off with free trade, and with the corresponding expanded markets, than they are with tariffs. To the extent that NAFTA organizes itself around economies of scale in the international trade within the region, the incentives for a trade war between NAFTA and the EC are mitigated.

It seems useful to remind ourselves that the choice of products and of technology are to a large extent the subject of policy. They need in no way interfere with market efficiency. The first welfare theorem about the efficiency of competitive markets applies to a market with given technologies and with given products. The theorem does not explain how different technologies or products arise: it proves that once technologies and products are given, competitive markets lead to Pareto efficiency. Once the product mix and the technologies are chosen the market can operate efficiently. This implies that the organizing principles within the blocs - traditional comparative advantages or economies of scale - are, to a great extent, a matter of policy choice. Choosing different trade policies, for example, choosing technologies and the product mix, can be achieved without market distortions or loss of market efficiency. This point was already made by Meade [18] several years ago.

The emergence of an American trading bloc which reinforces the current tendency towards the exploitation of traditional comparative advantages is a source of concern. It has been argued Chichilnisky [4], [5], [6] that export-led policies based on (unskilled) labor intensive products can defeat the goals of development and trade by depressing the country's terms of trade and overall consumption. Trade between the countries of the Americas is organized today around traditional comparative advantages: labor and resource intensive exports from the South and capital and skill-intensive exports from the North. If the emergence of an America free trade zone is 
based on similar principles, then not only may this continue a depressing growth trend in Latin America, but in addition it could create or reinforce incentives against the global liberalization of free trade.

We have argued that another reason to avoid trade policies between the countries of the Americas based on traditional comparative advantages is that they tend to deplete environmental assets such as forests, fisheries or fertile land, and overuse minerals which are exported by the developing countries to the North. Some of these minerals are the source of potentially dangerous $\mathrm{CO}_{2}$ emissions. Petroleum exported from Mexico, Ecuador and Venezuela to the USA fits this description. Indeed, any concept of sustainable development requires a rethinking of trade policies away from those based on comparative advantages. This general premise is particularly well suited to the NAFTA, and to the Americas as a whole, since two thirds of Latin American exports today are resources.

The main point of this paper is that the characteristics of trading policies within the trading blocs can determine the extent to which the blocs will favor or harm the global negotiations towards free trade. Trading policies based on comparative advantages are generally negative towards GATT. We argued that trading policies based on economies of scale could have the positive effect towards global free trade: they could mitigate the economic incentive of tariffs and trade restriction in favor of an expansion of world trade. The emergence of such blocs could advance in tandem with the global liberalization of world trade. 
this continue a addition it could ralization of free

d trade policies itional comparaental assets such erals which are Some of these $\mathrm{CO}_{2}$ emissions. zuela to the USA ole development those based on articularly well since two thirds

istics of trading ent to which the ards free trade. generally negabased on econlobal free trade: riffs and trade e emergence of liberalization of

\section{1. - Trading Blocs with Increasing Returns to Scale}

This appendix develops an international trade model and proves formally the propositions on customs unions stated in the body of the paper.

The model presented here extends the North-South model introduced in Chichilnisky [4], [5], [6], to the case of economies which trade goods produced under conditions of increasing returns to scale, and proves formally the proposition that with increasing returns to scale, large countries can achieve higher welfare levels with free trade than with tariffs. This model consider Cobb-Douglas production functions, and it assumes that there exist economies of scale in production which are external to the firm, such as in the example of the electronic industry discussed in the text.

The model describes two countries, 1 and 2, producing and trading two goods $B$ (basic goods) and $I$ (industrial goods) with each other; these goods are produced using two inputs, labor $L$ and capital, $K$. The economies of the two countries are competitive, so that in each country prices are taken as given by consumers and producers. Producers maximize profits, and consumers maximize utility subject ot their budget constraints. Walras' law is satisfied, so that the value of the excess demand is equal to zero. At an equilibrium all markets, for goods and for factors, clear.

The increasing returns to scale considered here are "external" to the firm as in the example of parts of the electronics industry discussed in the text. This means that in the production functions, formalized below, there exists a parameter denoted $\gamma$ which increases with the level of output of the economy. As the outputs of the economy expand, the production function varies, formalizing the notion that factors are more productive at higher levels of aggregate output. However, the firm takes this parameter $\gamma$ as given - this is the assumption that the increasing returns are external to the firm. 
For each given value of the parameter $\gamma$ the firm has constant returns to scale. The firms are therefore competitive, and in particular zero profits are achieved at an equilibrium.

Consider the model of one country first. The production functions are:

$$
\begin{aligned}
& B^{S}=\gamma L_{1}^{\alpha} K_{1}^{1-\alpha} \\
& I^{S}=\gamma L_{2}^{\beta} K_{2}^{1-\beta}
\end{aligned}
$$

where $\alpha, \beta, \in(0,1), \gamma$ is a positive parameter, $L_{1}$ and $K_{1}$ are the inputs of labor and capital in the $B$ sector, and $L_{2}$ and $K_{2}$ the inputs of labor and capital in the $I$ sector. The total amount of labor and capital in the economy are $L^{S}$ and $K^{S}$ respectively. Prices are $p_{B}$ and $p_{I}$; we assume that $I$ is the numeraire so that:

$$
p_{I}=1
$$

Factor prices are denoted as usual: $w$ for wages and $r$ for rental on capital. We shall assume for simplicity that the demand for basic goods at an equilibrium is known:

$$
B^{d}=\bar{B}^{d}
$$

so that by Walras' law the demand for industrial goods in equilibrium is given by:

$$
I^{d}=\left(w L^{S}+r K^{S}-p_{B} \bar{B}^{d}\right)
$$

because of zero profits. More general demand functions than those postulated in (18) can be given without a major effect on the results, see for example the various forms of demand functions utilized in Chichilnisky [6]. Indicating the equilibrium level of exports by $X_{B}^{S *}$ 
is constant returns in particular zero oduction functions $K_{1}$ are the inputs he inputs of labor and capital in the nd $p_{I}$; we assume

$s$ and $r$ for rental demand for basic

ds in equilibrium

tions than those t on the results, tions utilized in exports by $X_{B}^{S *}$ and the equilibrium level of imports by $X_{I}^{d *}$, the model of the world economy is formalized by the following equilibrium conditions:

$$
\begin{gathered}
p_{B}^{*} B^{S_{*}}+I^{*}=w^{*} L^{*}+r K^{*} \\
\text { (zero profits) } \\
K^{*}=K^{S}=K_{1}+K_{2} \\
\text { (capital market clears) } \\
L^{*}=L^{S}=L_{1}+L_{2} \\
\text { (labor market clears) } \\
B^{S_{*}}=B^{d_{*}}+X_{B}^{S *} \\
(B \text { market clears) } \\
I^{d_{*}}=I^{S_{*}}+X_{I}^{d_{*}} \\
(I \text { market clears) }
\end{gathered}
$$

\section{2. - Solving the Model}

The model for the world economy consists of two countries, indicated with the indices 1 and 2, each specified as above. To solve the model, there are therefore five prices to be determined: the "terms of trade" $p_{B}$, and two factor prices in each country: $w$ and $r$. The quantities to be determined in an equilibrium are: the use of factors in each sector of each country: $K_{1}, K_{2}, L_{1}, L_{2}$, the outputs of the two goods $B^{S}$ and $I^{S}$, and the corresponding parameter $\gamma$ determining the external economies of scale, the exports and imports of each of the two goods in each of the two countries, $X_{B}^{S *}$ and $X_{I}^{d *}$, and the demand for each good in each country: $B^{d *} I^{d *}$. There is a total of twenty seven variables to be determined endogenously, including all prices and quantities in all markets and both countries.

In the following proposition 1 we shall prove that all of these variables can be determined once the variable giving the terms of trade in equilibrium $p_{B}$ is known. Furthermore we shall prove that there exists one "resolving equation" which determines the equilib- 
rium value of the terms of trade as a function of all the exogenous parameters of the model, of which there are six in each country: $\alpha, \beta$, $\sigma, B^{d_{*}}, L^{S}$ and $K^{S}$, and a total of twelve in the world economy.

\section{The Effects of a Tariff on the Terms of Trade}

Proposition 1: if the importing country 1 has external economies of scale;

$$
\gamma=\gamma(B)=B^{\sigma}, \sigma>1
$$

and the foreign supply is highly elastic $\left(\partial X_{B}^{S 2} / \partial \mathrm{p}_{B}\right)>0$ and very large then no tariff can increase the welfare of the country relative to that which the country can achieve under free trade.

Proof: consider a world economy with two countries defined as in equations (16) (17) (18) (19) (20). We shall now solve the model by finding an explicit expression for the equilibrium terms of trade $p_{B}{ }^{*}$ in the world economy. This consists of writing the market clearing conditions in the $B$ market, exports equal imports, and expressing it as a function of one variable: $p_{B}$. From the terms of trade in equilibrium, we show that all other endogenous variables can be found. We shall use the indices 1 and 2 to distinguish the parameters of the two countries. Note first that we have given no specification of demand or supply behavior outside of an equilibrium; in particular, there is no information for carrying out stability analysis. Since the model has constant returns to scale, profit maximising supply functions are, as is standard, undefined. As is standard in models with constant returns to scale, we derive the equilibrium relations between supplies and prices from the condition of full employment of factors together with an equilibrium condition which incorporates the external economies of scale.

Denote:

$$
\begin{aligned}
& l_{1}=L_{1} / K_{1} \\
& l_{2}=L_{2} / K_{2}
\end{aligned}
$$


all the exogenous ach country: $\alpha, \beta$, orld economy.

de

sternal economies

в) $>0$ and very ountry relative to le.

tries defined as in lve the model by ns of trade $p_{B}{ }^{*}$ in market clearing and expressing it ms of trade in variables can be the parameters specification of m; in particular, alysis. Since the ing supply funcin models with elations between ment of factors rates the extern-

Since by assumption each firm takes the parameter $\gamma$ as given, from the production functions (16), marginal conditions and zero profits imply:

$$
\begin{gathered}
w=\gamma \alpha\left(L_{1} / K_{1}\right)^{\alpha-1} p_{B}=\gamma \alpha l_{1}^{\alpha-1} p_{B} \\
r=\gamma(1-\alpha) l_{1}^{\alpha} p_{B} \\
w=\gamma \beta l_{2}^{\beta-1} \\
r=\gamma(1-\beta) l_{2}^{\beta}
\end{gathered}
$$

so that:

$$
\frac{r}{w}=\left[\frac{(1-\alpha)}{\alpha}\right] l_{1} \text { and } \frac{r}{w}=\left[\frac{(1-\beta)}{\beta}\right] l_{2}
$$

and in particular:

$$
l_{1}=\frac{[(1-\beta) \alpha]}{[\beta(1-\alpha)]} l_{2}
$$

Our next step is to define an equation (called the "resolving equation" and denoted $F=0$ ) which yield the equilibrium value of the terms of trade $p_{B}$ as a function of all the exogenous parameters of the model of which there are 12 as listed above, and from which all other endogenous variables at equilibrium are explicitly computed.

Indicating logarithms with the symbol "-" the four equations in (21) can be rewritten as:

$$
\begin{gathered}
\tilde{w}=(\alpha-1) \tilde{l}_{1}+\tilde{\alpha}+\tilde{p}_{B}+\tilde{\gamma} \\
\tilde{r}=\tilde{\alpha} \tilde{l}_{1}+(1 \simeq \alpha)+\tilde{p}_{B}+\tilde{\gamma} \\
\tilde{w}=(\beta-1) \tilde{l}_{2}+\tilde{\beta}+\tilde{\gamma} \\
\tilde{r}=\beta \tilde{l}_{2}+(1-\beta)+\tilde{\gamma}
\end{gathered}
$$

so that:

$$
\begin{aligned}
& (\alpha-1) \tilde{l}_{1}+\tilde{\alpha}+\tilde{p}_{B}=(\beta-1) \tilde{l}_{2}+\tilde{\beta} \\
& \alpha \tilde{l}_{1}+(1 \simeq \alpha)+\tilde{p}_{B}=\beta \tilde{l}_{2}+(1 \simeq \beta)
\end{aligned}
$$


or equivalently:

(26)

$$
\begin{aligned}
& (\alpha-1) \tilde{l}_{1}+(1 \simeq \beta) \tilde{l}_{2}=\tilde{\beta}-\tilde{p}_{B}-\tilde{\alpha} \\
& \tilde{\alpha} \tilde{l}_{1}-\beta \tilde{l}_{2}=(1 \simeq \beta)-\tilde{p}_{B}-(1 \simeq \alpha)
\end{aligned}
$$

Solving for $\tilde{l}_{1}, \tilde{l}_{2}$ we obtain:

(27) $\tilde{l}_{1}=\frac{\left[\left(\tilde{\beta}-\tilde{p}_{B}-\tilde{\alpha}\right)(-\beta)-(1-\beta)\left[(1 \simeq \beta)-\tilde{p}_{B}-(1 \simeq \alpha)\right]\right.}{[\beta-\alpha]}-$

and:

(28) $\tilde{l}_{2}=\frac{\left[(\alpha-1)\left[(1 \simeq \beta)-\tilde{p}_{B}-(1 \simeq \alpha)\right]-\left[\left(\tilde{\beta}-\tilde{p}_{B}-\tilde{\alpha}\right) \alpha\right]\right]}{[\beta-\alpha]}$

From (27) and (28) we obtain:

$$
\tilde{l}_{1}=\frac{\tilde{p}_{B}}{(\beta-\alpha)}+A
$$

and:

$$
\tilde{l}_{2}=\frac{\tilde{p}_{B}}{(\beta-\alpha)}+B
$$

where:

$$
A=\frac{[(\tilde{\beta}-\tilde{\alpha})(-\beta)-(1-\beta)[(1 \simeq \beta)-(1 \simeq \alpha)]]}{(\beta-\alpha)}
$$

and:

$$
\begin{gathered}
B=\frac{[\alpha-1)[(1 \simeq \beta)-(1 \simeq \alpha)]-\alpha(\tilde{\beta}-\tilde{\alpha})}{(\beta-\alpha)} \\
A>0 \text { and } B<0 \text { if } \beta<\alpha
\end{gathered}
$$


Therefore:

$$
l_{1}=e^{A} p_{B}^{1 /(\beta-\alpha)}
$$

and:

$$
l_{2}=e^{B} p_{B}^{1 /(\beta-\alpha)}
$$

Now:

(31)

$$
l_{2}=\frac{\left(L^{S}-L_{1}\right)}{K^{S}-K_{1}} \Rightarrow L^{S}-L_{1}=l_{2}\left(K^{S}-K_{1}\right)
$$

or:

$$
L_{1}=L^{S}-l_{2}\left(K^{S}-K_{1}\right)
$$

and:

$$
l_{1}=L_{1} / K_{1} \Rightarrow L_{1} l_{1} K_{1}
$$

so that:

$$
L^{S}-l_{2}\left(K^{S}-K_{1}\right)=l_{1} K_{1}
$$

or:

$$
K_{1}\left(l_{1}-l_{2}\right)=L^{S}-l_{2} K^{S} \Rightarrow K_{1}=\left(L^{S}-l_{2} K^{S}\right) /\left(l_{1}-l_{2}\right)
$$

From (31) (32) (33) we obtain:

$$
K_{1}=\frac{\left(L^{S}-l_{2} K^{S}\right)}{\left(l_{1}-l_{2}\right)}
$$

and:

$$
L_{1}=\frac{\left(l_{1}\right)}{\left(l_{1}-l_{2}\right)}\left(L^{S}-l_{2} K^{S}\right)
$$


from which together with (30) we obtain the levels of supply of labor and capital used in each sector, at an equilibrium as a function of the equilibrium level of the relative price of $B$ :

$$
L_{1}=\frac{e^{A} L^{S}}{\left(e^{A}-e^{B}\right)}-\frac{e^{A} e^{B}}{\left(e^{A}-e^{B}\right)} K^{S} p_{B}^{1 /(\beta-\alpha)}
$$

and:

$$
K_{1}=\frac{L^{S}}{e^{A}-e^{B}} p_{B}^{1 / \alpha-\beta}-e^{B}\left(e^{A}-e^{B}\right) K^{S}
$$

From (16) (36) we obtain the quantity of $B$ and $I$ produced at each level of relative prices, $p_{B}$. Now taking $\gamma=1$, we denote these as $\phi$ $\left(p_{B}\right)$ and $\psi\left(p_{B}\right)$ respectively. Therefore from (16) we obtain the equilibrium level of outputs as a function of equilibrium prices:

$$
B^{S}=\gamma \phi\left(p_{B}\right)
$$

and:

$$
I^{S}=\gamma \psi\left(p_{B}\right)
$$

Note that this does not fully express output as an explicit function of equilibrium prices because $\gamma=\gamma(B)$. In order to obtain outputs as explicit functions of equilibrium prices we must also find out the equilibrium value of $\gamma=\gamma^{*}(B)$, which is "fixed point" problem, since $\gamma$ depends on $B$ and $B$ depends on $\gamma$. We solve this as follows.

The economy has increasing returns which are external to the firm, and the parameter $\gamma$ increases with the level of output of $B$ and I:

$$
\gamma=B^{\sigma}
$$

At an equilibrium equations (38) and (39) must be satisfied simultaneously, i.e.:

$$
\begin{gathered}
\gamma=\left[\gamma \cdot \phi\left(p_{B}\right)\right]^{\sigma} \\
=\gamma^{\sigma} \phi\left(p_{B}\right)^{\sigma} \text { or } \gamma^{1-\sigma}=\phi\left(p_{B}\right)^{\sigma}
\end{gathered}
$$


supply of labor function of the

oduced at each note these as $\phi$ we obtain the um prices:

xplicit function tain outputs as 0 find out the problem, since s follows.

xternal to the utput of $B$ and

it be satisfied so that:

$$
\gamma=\phi\left(p_{B}\right)^{\sigma /(1-\sigma)}
$$

Therefore at an equilibrium from (38) we obtain a relation between the outputs of $B$ and $I$, and $p_{B}$ :

$$
\begin{aligned}
& B^{S}=\phi\left(p_{B}\right)^{\sigma+1 /(1-\sigma)} \\
& I^{S}=\psi\left(p_{B}\right)^{\sigma+1 /(1-\sigma)}
\end{aligned}
$$

Note that:

$$
\text { when } \sigma>1, \theta=\sigma+1 / 1-\sigma<0
$$

so that when $B^{S}=\phi\left(p_{B}\right)^{\sigma+1 /(1-\sigma)}$ decreases with $p_{B}$ across equilibria, since $\phi\left(p_{B}\right)$ is an increasing function of $p_{B}$ for each fixed $\gamma$, see Graph 3.

If $\sigma \rightarrow 1, \theta \rightarrow-\infty$.

To solve the model we now consider the market clearing condition in $B$. At a world equilibrium, the $B$ market must clear so that:

$$
B^{d, 1}\left(p_{B}+t\right)-\mathrm{B}^{s, 1}\left(p_{B}+t\right)=B^{s, 2}\left(p_{B}\right)-B^{d, 2}\left(p_{B}\right)
$$

or:

$$
F\left(p_{B}, t\right)=B^{d, 1}\left(p_{B}+t\right)-B^{s, 1}\left(p_{B}+t\right)-B^{s, 2}\left(p_{B}\right)+B^{d, 2}\left(p_{B}\right)=0
$$

From (18) (19) (21) (30) and (41), equation (42) is a function of the variable $p_{B}$ alone, which we call a reduced form "resolving" equation for this model. Solving this equation gives the equilibrium values of $p_{B}$ from where all other variables can be computed as shown above. The model is thus solved.

We may now study the changes in the terms of trade as a function of the tariff $t$. By the implicit function theorem:

$$
\begin{gathered}
\partial p_{B} / \partial t=\frac{-\partial F / \partial t}{\partial F / \partial p_{B}} \\
-\left(\partial \left(B^{d, 1}-B^{s, 1} / \partial\left(p_{B}+t\right)\right.\right. \\
=\frac{B^{d, 1} / \partial\left(p_{B}+t\right)+\partial B^{d, 2} / \partial p_{B}-\partial B^{s, 1} / \partial\left(p_{B}+t\right)-\partial B^{s, 2} / \partial P_{B}}{D}
\end{gathered}
$$


GRAPH 3

EACH FIRM FACES AN UPWARD COST CURVE.

THE COUNTRY AS A WHOLE FACES A DOWNWARD COST CURVE DUE TO EXTERNAL ECONOMIES OF SCALE

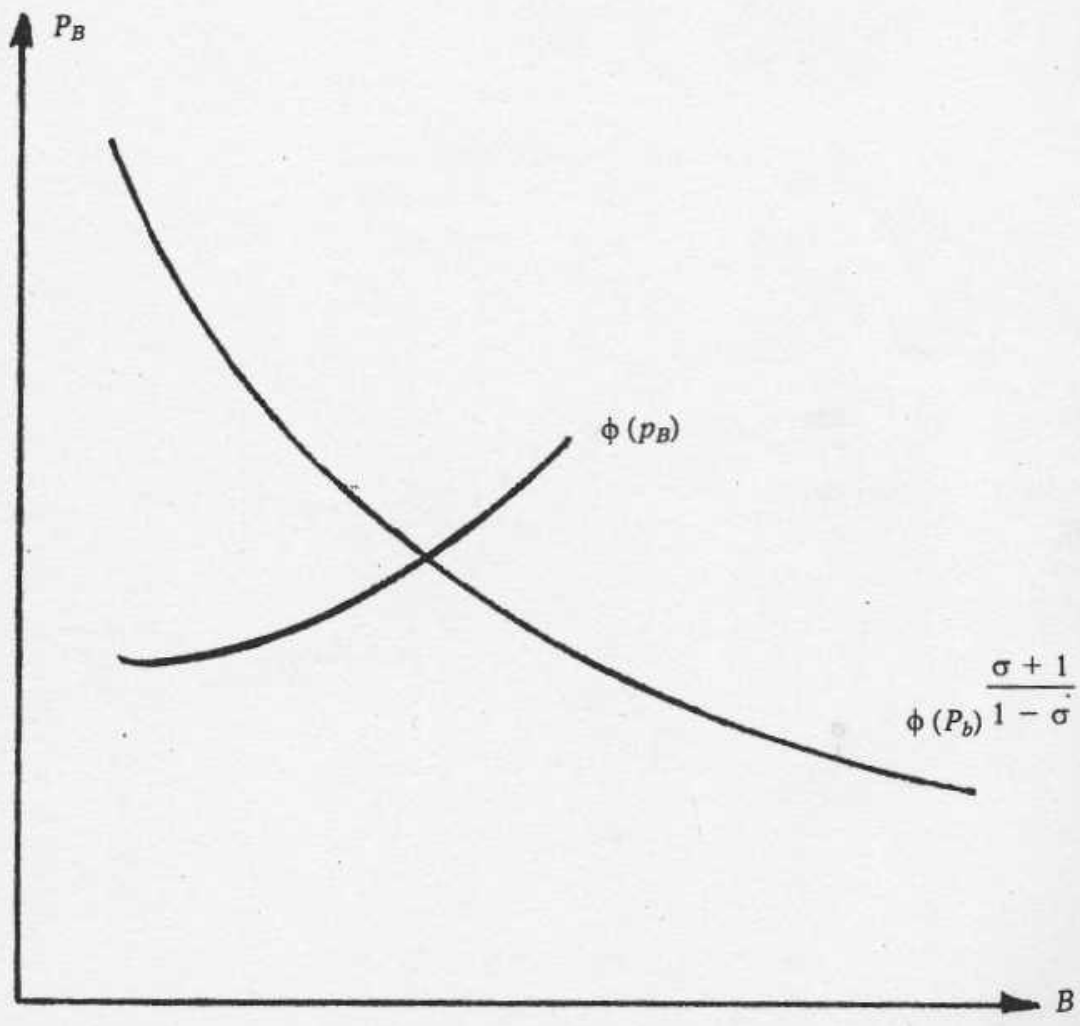

By the assumptions on demand for $B$, if $\sigma_{1}>1$, then $\partial B^{s, 1} / \partial\left(p_{B}\right.$ $+t)<0$ and therefore the numerator of (43) is negative. The denominator is also negative, so that $\partial p_{B} / \partial t>0$. As the tariff $t$ increases, $p_{B}$ also increases. The terms of trade of the country decrease, since it imports $B$ and must now pay more for it, as we wished to prove. 


\section{BIBLIOGRAPHY}

URVE.

\section{LD COST CURVE}

CALE

[1] Amelung T.: «Tropical Deforestation as an International Economic Problem», Linz (Austria), Egon Sohmen Foundation, Paper presented at the Conference on Economic Evolution and Environmental Concerns, August 30-31, 1991.

[2] BARBIER E.B. - BURGER J.C. - MARKANDYA A.: «The Economics of Tropical Deforestation", Ambio, vol. 20, n. 2, 1991, pp. 55-8.

[3] BinKLeY C.S. - VinCENT J.R.: «Forest Based Industrialization: a Dynamic Perspective», Washington (D.C.), World Bank, Forest Policy Issues Paper, 1990.

[4] CHICHILNISKY G.: «Terms of Trade and Domestic Distribution: Export Led Growth with Abundant Labor", Journal of Development Economics, n. 8, 1981, pp. 163-92.

[5] Chichilnisky G. - HeAL G.: The Evolving International Economy, Cambridge, Cambridge University Press, 1987.

[6] CHICHILNISKY G.: "A General Equilibrium Theory of North-South Trade», Part 1: Equilibrium Analysis, Essays in Honor of Kenneth Arrow, Cambridge, Cambridge University Press, 1986, pp. 3-56.

[7] - - «Global Environment and North-South Trade», Stanford, Stanford Institute for Theoretical Economics, Stanford University, Technical Report, n. 31, 1991.

[8] _ - "North-South Trade and the Dynamics of Renewable Resources», Columbia University, Working Paper, 1992.

[9] _ - : «Customs Unions with Economies of Scale», Columbia University, Working Paper, 1992.

[10] DADZIE K.: «Accelerating the Development Process: Challenges for National and International Policies in the 1990's", Report by the Secretary General of UNCTAD to UNCTAD VIII, New York, United Nations Conference on Trade and Development, 1991.

[11] Hyde W.F. - Neumann D.H.: «Forest Economics in Brief-with Summary Observations for Policy Analysis», Washington (DC), World Bank, First Report on Agricoltural and Rural Development, 1991.

[12] KenNAN J. - RIEZMAN R.: «Do Big Countries Win Tariff Wars», International Economic Review, vol. 29, n. 1, 1988, pp. 81-5.

[13] _- - : :Optimal Tariff Equilibria with Customs Union», Canadian Journal of Economics, vol. XXIII, n. 1, 1990, pp. 70-83.

[14] Krugman P.: "The Move to Free Trade Zones», Department of Economics, MIT, Working Paper, 1991.

[15] Krugman P. - ObstFelt M.: International Economics, Illinois, Boston, London, Scott, Foresman and Company, 1988.

[16] LERNER A.: "The Symmetry Between Import and Export Taxes», Economica, n. 3, 1936, pp. 306-13.

[17] MEADE J.: The Theory of Customs Unions, Amsterdam, North-Holland, 1955.

[18] — - The Theory of Indicative Planning, London, Allen Unwin, 1971.

[19] MetzleR L.: «Tariffs the Terms of Trade and Distribution of National Income», Journal of Political Economy, n. 57, 1949, pp. 1-29.

[20] Nicholson W.: Microeconomic Theory, Hinsdale (il.), The Dryden Press, 1978.

[21] RIEzman R.: "Customs Unions and the Core", Journal of International Economics, n. 19,1985 , pp. 355-65.

[22] Viner J.: The Customs Union Issue, New York, Carnegie Endowment for International Peace. 